\title{
三次元光導波路とくし歯形静電アクチュエータの 集積化デバイスの試作
}

\author{
正員 斉藤 秀典 正員 藤田 博之（東京大学） \\ Trial Fabrication of a Movable 3-D Optical Waveguide \\ Integrated with a Comb-type Electrostatic Microactuator \\ Hidenori Saito, Member, Hiroyuki Fujita, Member (The University of Tokyo) \\ キーワード: 光導波路, マイクロマシニング, アクチュエータ, シリコン酸化窒化膜
}

最近，半導体作製技術を用いたマイクロマシニングにより 静電モータや種々のアクチュエータが作られている。マイク ロアクチュエータの有㕵な応用分野の一つに, 微小光学系か ある。网者を融合できれば，マイクロメカノプティクスと称 すべき，新しい可能性が広がる。この時，シリコン基板止に 3 次元光尊波路亡マイクロアクチュエータを集積化できるプ ロセスは，極めて重要である。超小型の光スイッチや切替器， 干渉計, 光集積回路の人出力端での能動的アライメント等, 種々の応用がある。今回は, 半導体マイクロマシニング技術 を用いて, 3 次元光導波路とマイクロアクチュエータとを一 体集積化したデバイスの試作を行ったので報告する。

今回試作した 3 次元光導波路とマイクロアクチュエータを 一体化したテバイスの概略図を図 1 に示寸。3 次元光導波路 は，分岐点で可動部(A)と比較用の固定部(B)に分かれる。基板 尔ら分離した両持ち梁の上部を, 光導波路(A)が通る。梁はマ イクロアクチュエータにより変形可能である。将来(A), (B)の 出力光を干涉させ，変位計とすることを目指している。

本研究では光導波路の材料として, シリコン酸化窒化膜(以 下，SiON)を用いた。SiONはそこに含まれるOとNの組成比に よって $\mathrm{SiO}_{2}$ (屈折率 $\left.\mathrm{n}=1.46\right)$ と $\mathrm{Si}_{3} \mathrm{~N}_{4}(\mathrm{n}=2)$ の間の屈折率にな る。すなわち○が多いほど屈折率は1.46に近づき，Nが多いほ と2に近つく。SiONは高周波(RF)スパッタリング法で成膜し た。 $\mathrm{SiO}_{2}: \mathrm{Si}_{3} \mathrm{~N}_{4}=9: 1$ の組成のターゲットを用いた。反応 ガスは $\mathrm{Ar}$ と $\mathrm{N}_{2}$ である。反応ガスが ArのみであるとSiON 薄 膜は不透明になってしまう。またArと $\mathrm{N}_{2}$ の分圧比を変えてス パッタしたSiON薄膜の屈折率を測定したところ, その分圧比 によって薄膜の屈折率は変化した。これは，反応性スパッ夕 リングが起こっているためであると考えられる(1)。今回はA と $\mathrm{N}_{2}$ の比を 1 対 1 とて成膜したSiON膜 $(\mathrm{n}=1.52)$ をコアに用い た。 3 次元光導波路のコアは, 厚み $250 \mathrm{~nm}$, 幅 $2 \mu \mathrm{m}$ とした。 本研究ではマイクロアクチュエータとして, 表面マイクロ マシーニングを用いて作製できるくし型アクチュエータを選 んだ。アクチュエータの構造材料の $\mathrm{SiO}_{2}$ 薄膜は, 圧縮性の内 部応力が入る場合が多い。圧縮性の内部応力により，雨持ち 梁などの構造は座屈する恐れがある。したがってその圧縮応
力を極力低減する方法を試みた。 $\mathrm{SiO}_{2}$ をスパッ夕により成膜 するときスパッタ中の反応ガス圧力が高いほど, 王縮応力が 緩和される傾向がある(1)。このため，〈し型マイクロアクチ ュエータの構造材料となる $\mathrm{SiO}_{2}$ は, 反応ガス圧を高くして(反 态ガス: Ar, 压力: 4Pa 程度), スパッ夕法によって成膜するこ ととした。また，スパッ夕法によって成膜された $\mathrm{SiO}_{2}$ 薄膜の 屈折率を测定し， $\mathrm{n}=1.47$ を得た。反応ガス圧力を高くしてス パッタした $\mathrm{SiO}_{2}$ 薄膜についても，これを光導波路のクラッド および基板として用いることができることを確認した。 マイクロアクチュエータの構造材料は絶縁体であるので、 これを静電力で呕動するためには，上面と侧面を導電性の材 料(金属)で覆う必要がある。侧面にも薄膜を付着するには， スパッ夕法が有効である。したがって，マイクロアクチュエ 一タをリリース後、スパッ夕によって金属 $(\mathrm{Cr} / \mathrm{Cu})$ を堆積した。 これにより, マイクロアクチュエータは導電性を持つように なり，静電力による眍動が可能になった。

図 2 にこのデバイスの作製プロセスを示す。これは図1の A-A'断面の様子を表している。

(a) $\mathrm{Si}$ 基板上に $\mathrm{SiO}_{2}(2 \mu \mathrm{m}), \mathrm{SiON}(250 \mathrm{~nm})$ をスパッタする。

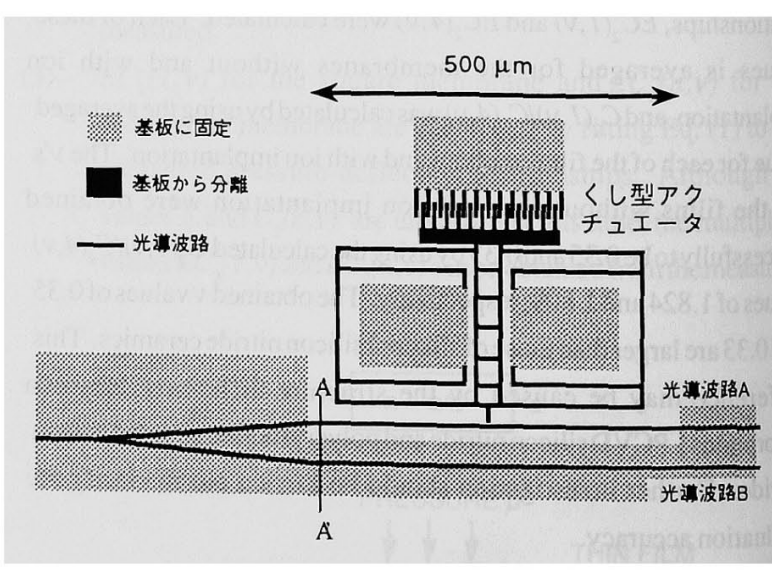

図1マイクロアクチュエータと 3 次元光導波路とを一体化し たデバイスの概略図

Fig. 1 Schematic representation of a device composed of a microactuator and an optical waveguide. 
(b) Niを蒸着し，フォトレジスト (以下P.R.)を溉布して，露 光，現像する。Niをエッチングし，P.R.を剥離する。

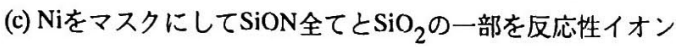
エッチング (以下RIE) により、エッチング断面が基板と韭 直になる異方性エッチングを行う。エッチングガスには， $\mathrm{CHF}_{3}$ と等を用いた。

(d) $\mathrm{Niを}$ 剥離して $\mathrm{SiO}_{2}(2 \mu \mathrm{m})$ をスパッタにより堆積する。

(e) Niを蒸着し、マイクロ構造の形にエッチングする。

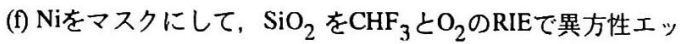
チングする。

（g）基板のシリコンを $\mathrm{SF}_{6}$ のRIEで等方性エッチングし，構造 を基板から分離（リリース）する。

(h) スパッ夕により Cr $(10 \mathrm{~nm})$ とCu $(100 \mathrm{~nm})$ を堆積する。

図 3 に製作したくし型マイクロアクチュエータの電子顕微 鏡写真を示した。内部応力を完全に除去できなかったため, マイクロアクチュエータのサスペンション部分などはわずか に撓んでいるのがわかる。四4にマイクロアクチュエータの 呕動電圧と変位の関係を示した。駆動電圧を上げると,急に変 位が大きくなる。これはアクチュエータのサスペンションに
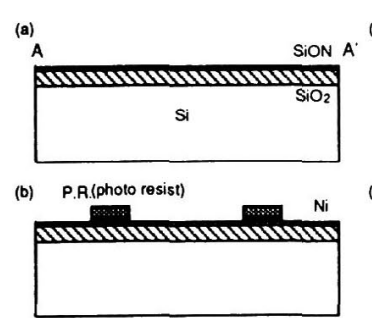

(c)

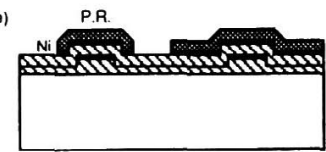

(f)
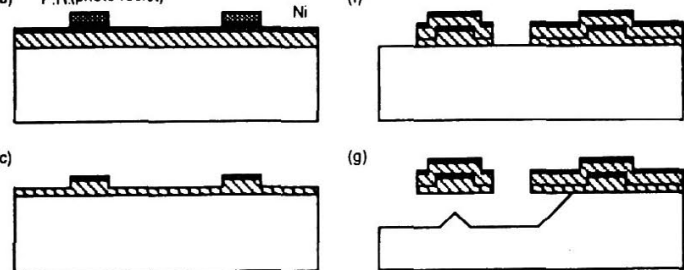

(9)

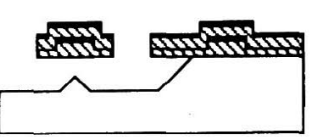

(d)
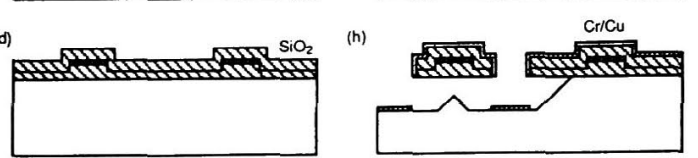

図 2 作製プロセス

Fig. 2 Fabrication process.

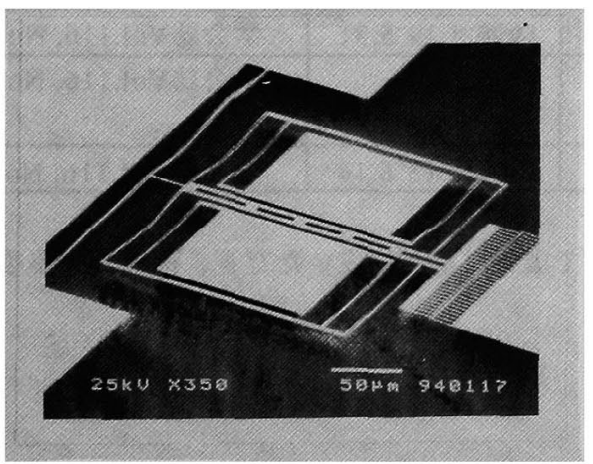

図 3 試作したデバイス

Fig. 3 Microphotograph of the device.

内部圧縮応力が入っているために,そのばね定数が非線形にな っているためと考えられる。また，基板を䢃開し，光導波路 の端面からHeNeレーザ光を導入したところ, 他端まで光が導 波されていることが確認できた。しかし，減衰は $10 \mathrm{~dB} / \mathrm{cm}$ 以 上と極めて大きかった。

以上，半導体マイクロマシニング技術を用いて， 3 次元光 導波路とマイクロアクチュエータとを一体化したデバイスの 試作を行った。また，アクチュエータが実際に 3 次元光導波 路を駆動可能なことを確かめた。

今後は，内部応力の低減と光導波特性の向上のため,さら にプロセスを改良する必要がある。

末筆ながら，光導波路の测定において，お世話になった本 研究所第 3 部藤井陽一教授および藤井研究室の近藤由紀子助 手に深く感謝致します。

(平成 7 年 8 月 31 日受付) 文献

（1）金原, スパタリング現象, 東京大学出版会 (1984)

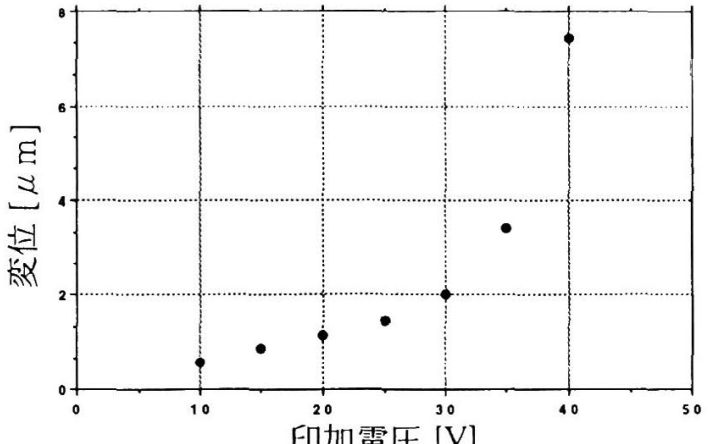

図4 マイクロアクチュエータの駆動電圧之変位の関係 Fig. 4 Displacement of the microactuator as a function of applied voltage.

斉藤秀典

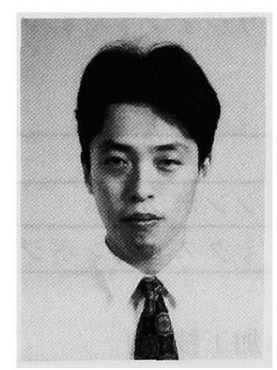

藤田博之

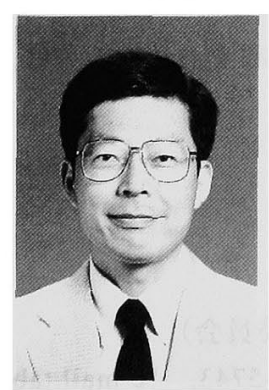

（正員）昭和 45 年 2 月 18 日生。 平成 4 年 3 月東京大学工学部電子工学 科卒業。6 年 3 月同大学院工学系研究 科電気工学専攻修士課程修了。主とし て、マイクロメカトロニクスの光学応 用に関寸る研究に従事。現在、北陸電 力株式会社に勤務。

（正員） 昭和 27 年 12 月 13 日生。 昭和 50 年 3 月東京大学工学部電気工 学科卒業。5 2 年 3 月同大学院にて工 学修士、 55 年 3 月工学博士。同年 4 月より東京大学生産技術研究所講師、 助教授を経て、平成 5 年 8 月より同教 授。主としてマイクロメカトロニクス の研究に従事。 